\title{
Analysis of the Performance of Islamic Commercial Banks in Indonesia Using the Islamicity Performance Index Approach for the 2014-2016 periods
}

\author{
Effendy Sadly \\ Faculty of Economics, North Sumatera Islamic University, Medan, 20217, Indonesia \\ gusnaidihamid@gmail.com \\ *Corresponding Author: gusnaidihamid@gmail.com
}

\begin{abstract}
This study aims to reveal the application of Islamic principles to the performance of Islamic Commercial Banks in Indonesia for the 2014 to 2016 period using the Islamicity Performance Index approach. The ratios in the Islamiciti Performance Index are Profit Sharing Ratio, Zakat Performance Ratio, Equitable Distribution Ratio, Directorsemployee Wefare Ratio, Islamic Income vs Non-Islamic Income. The data used in this study are secondary data. The population of this research is all Islamic commercial banks in Indonesia from 2014 to 2016 with a sample of two banks, namely Bank Muamalat Indonesia and Bank Syariah Mandiri. Sampling was done using purposive sampling method. The results showed that the performance of Islamic Commercial Banks in Indonesia using the Islamicity Performance Index approach for the period 2014 to 2016 has the predicate "Not Good". There are several unsatisfactory ratios, namely the Zakat Performance ratio, the Equitable Distribution ratio, and the Directors-Employee Ratio. From the results of performance calculations using the Islamicity Performance Index approach among the three banks, namely Bank Muamalat Indonesia, Bank Syariah Mandiri, and Bank BRI Syariah, it shows that the three banks both get the predicate "Good Enough".
\end{abstract}

Keywords: performance; islamic performance index; islamic commercial bank

\section{Introduction}

In Indonesia, the development of sharia-based banks is experiencing rapid progress. This shows that the development of the Islamic economy in Indonesia is starting to show real success. It is common knowledge that the development of the Islamic economy is identical to the development of Islamic financial institutions. Islamic banks as the main motor of financial institutions have become the locomotive for the development of Islamic economic theory and practice in depth (Karim, 2004). Banking performance can be seen through the financial reports made every period. Analysis of Islamic bank financial statements in this case is done using the Islamicity Performance Index. Using the Islamicity Performance Index can make it easier for stakeholders to evaluate the performance of Islamic banks, not only from a financial perspective but also able to evaluate the principles of justice, halalness, and purification (Tazkiyah) that are carried out by Islamic commercial banks. There are six financial ratios measured from the Islamicity Performance Index, namely Profit Sharing ratio, Zakat Performance Ratio, Equitable distribution Ratio, Directors-employee wefare Ratio, Islamic investment vs non-Islamic investment ratio, Islamic income vs non-Islamic income. Islamic Bank According to Law no. 10 of 1998 concerning Sharia Banking states that Islamic Banks are banks that carry out their business activities based on sharia principles and according to their types consist of Islamic commercial banks and Islamic banking banks.

The definition of Sharia Bank according to Siamat, Dahlan (2004) describes the notion of a Sharia Bank as a bank which in running its business is based on legal or sharia principles by always referring to the Koran and Al-Hadith. Islamicity Performance Index The Islamicity Performance Index is a tool or method capable of expressing the materialistic and spiritual values that exist in Islamic banks. This method can evaluate the performance of Islamic banks, not only from a financial perspective but also able to evaluate the principles of justice, halalness and sanctification (tazkiyah) carried out by Islamic commercial banks. Hameed, et. al. (2004) in their research has developed an index called the Islamicity Performance Index which consists of six ratios measured from the Islamicity Performance Index, namely Profit Sharing Ratio, Zakat Performance 
Ratio, Equitable Distribution Ratio, Directors-Employes Wefare Ratio, Islamic Investment vs Non-Islamic Investment. Ratio, Islamic Income vs Non Islamic Income.

Profit Sharing Ratio. Profit Sharing Ratio (profit sharing) is one of the main objectives of Islamic banking. Therefore it is very important to know how far Islamic banking has succeeded in achieving their existence on profit sharing through Profit Sharing Ratio. Profit sharing income can be obtained with two contracts consisting of a mudharabah contract, namely the investment of funds from the owner to the fund manager to carry out certain business activities, with a distribution based on profit and los sharing. The second contract is musyarakah, which is an agreement between the owners of the capital to mix their capital in a certain business with a profit sharing that has been agreed upon beforehand, and also the loss is borne by all owners of the capital based on their share of capital. Profit Sharing Ratio is calculated by adding up the financing from the mudharabah and musyarakah contracts then compared to the total financing, following the Profit Sharing Ratio (PSR) formula. Zakat Performance Ratio. Zakat is one of the commands in Islam so it must be one of the goals of Islamic accounting. Therefore, the performance of Islamic banking must be based on zakat paid by banks to replace conventional performance indicators, namely earning per share, bank assets must be based on net assets rather than net income emphasized by conventional methods. So that if the bank has high net assets, the higher the zakat that must be paid.

\section{Materials and Methods}

\subsection{Research Location, Materials and Tools}

Research locations are Islamic Commercial Banks in Indonesia, which are listed in the directory of Bank Indonesia for the 2014-2016 period, namely 13 Islamic Banks. The data source used in this research is secondary data in the form of financial reports from Islamic Commercial Banks in Indonesia in the 2014-2016 periods, the data is obtained through annual reports published by Bank Indonesia (BI), the Financial Services Authority (OJK), the Central Agency. Statistics (BPS), and the official Banking Website under study. Secondary data is data that is already available so that researchers can find and collect it, secondary data can be obtained more easily and quickly because it is already available in companies. The type of data in this study uses secondary data with external data types. External data is data that is generally compiled by an entity other than researchers from the organization concerned. Data collection is done by searching using a computer that can be accessed by the internet (Internet System). The population used in this study are Islamic Commercial Banks in Indonesia, which are listed in the directory of Bank Indonesia for the 2014-2016 period, namely 13 Islamic Banks. The The time of this research was year 2014-2016 period. The following is a list of sample banks consisting of 13 banks that have been included in the table 1 .

Table 1. Name of Banks

\begin{tabular}{|c|c|}
\hline No & Name of Banks \\
\hline 1 & PT. Bank Aceh Syariah \\
\hline 2 & PT. Bank Muamalat Indonesia \\
\hline 3 & PT. Victoria Syariah \\
\hline 4 & PT. BRI Syariah \\
\hline 5 & PT. Bank Jabar Banten Syariah \\
\hline 6 & PT. Bank BNI Syariah \\
\hline 7 & PT. Bank Syariah Mandiri \\
\hline 8 & PT. Bank Mega Syariah \\
\hline 9 & PT. Bank Panin Syariah \\
\hline 10 & PT. Bank Syariah Bukopin \\
\hline 11 & PT. Bank BCA Syariah \\
\hline 12 & PT. Maybank Syariah Indonesia \\
\hline 13 & PT. Bank Tabungan Pensiunan Nasional Syariah \\
\hline
\end{tabular}

\section{Results and Discussions}

The Based on this ratio, Bank Muamalat Indonesia contributed 50.81\% in 2014 and experienced an increase of $54.39 \%$ in 2015, and in 2016 it decreased to $54.21 \%$. Based on this ratio, Bank Muamalat Indonesia provided a portion of $0.022 \%$ in 2014 and continued to increase in 2015 and 2016, namely with a portion of $0.029 \%, 0.040 \%$. Based on this ratio, Bank Muamalat Indonesia for aid and qard funds in 2014 amounted to 
$6.18 \%$ and in 2015 increased by $98.70 \%$ then in 2016 experienced a decrease of $32.37 \%$. Based on this ratio, Bank Muamalat Indonesia in 2014 provided a salary of 63 times the salary to the board of directors compared to employee welfare. In 2015 it has increased to 76 times and in 2016 it has decreased to 15 times. Bank Muamalat Indonesia from 2014 to 2015 increased director salaries several times, making a significant difference to employee salaries.

Based on this ratio, Bank Muamalat Indonesia in 2014 gave a percentage of 99.81\%, then in 2015 it increased by $99.93 \%$ and in 2016 decreased by $99.92 \%$. Based on this ratio, Bank Syariah Mandiri contributed 21.03\% in 2014 and increased in 2015 and 2016, namely 24.95\% to 29.16\%. Based on this ratio, Bank Sayariah Mandiri provided a portion of $0.004 \%$ in 2014 and continued to decline in 2015 by $0.001 \%$ and in 2016 increased by $0.016 \%$.

Based on this ratio, Bank Syariah Mandiri for aid and qard funds in 2014 amounted to $88.43 \%$ and in 2015 decreased by $13.82 \%$ then in 2016 increased by $145.82 \%$. The percentage of total funds distributed to employees in 2014 was $33.51 \%$, decreased in 2015 by $20.51 \%$, and in 2016 experienced an increase of $110.31 \%$. The percentage of total funds distributed to shareholders in 2014 was $0.40 \%$ and in 2015 decreased by $0.031 \%$ and in 2016 increased by 7.93\%. Income for Bank Syariah Mandiri which was recognized as net profit in 2014 namely $1.76 \%$, and an increase in 2015 and 2016 by $3.07 \%, 24.17 \%$.

Based on this ratio, Bank Syariah Mandiri in 2014 provided 30 times the salary to the board of directors compared to employee welfare. In 2015 it decreased to 21 times and in 2016 it had increased to 23 times. Bank Syariah Mandiri in 2014 reached 30 times and in 2015 experienced a decline and in 2016 has increased again several times.

Table 1. The Results of the Profit Sharing Ratio

\begin{tabular}{|c|c|c|c|}
\hline Years & Indonesia Muamalat Bank & Scores & Predicates \\
\hline 2014 & $49,37 \%$ & 2 & Pretty good \\
\hline 2015 & $54,39 \%$ & 3 & Good \\
\hline \multirow[t]{3}{*}{2016} & $54,21 \%$ & 3 & Good \\
\hline & Total & 8 & \\
\hline & Average & 2 & Pretty Good \\
\hline
\end{tabular}

Table 2. Zakat Performance Ratio Results

\begin{tabular}{|c|c|c|c|}
\hline Years & Indonesia Muamalat Bank & Scores & Predicates \\
\hline 2014 & $0,022 \%$ & 1 & Not Good \\
\hline 2015 & $0,029 \%$ & 1 & Not Good \\
\hline \multirow[t]{3}{*}{2016} & $0,040 \%$ & 1 & Not Good \\
\hline & Total & 3 & \\
\hline & Average & 1 & Not Good \\
\hline
\end{tabular}

Table 3. Equitable Distribution Ratio Results

\begin{tabular}{cccccc}
\hline Year/Ratios & 2014 & 2015 & 2016 & Scores & Predicates \\
\hline Qard and Donation & $6,18 \%$ & $98,70 \%$ & $32,37 \%$ & 2 & Good Enough \\
\hline Employes Expense & $40,49 \%$ & $39,58 \%$ & $51,92 \%$ & 2 & Good Enough \\
\hline Shareholders & $0,027 \%$ & $0,011 \%$ & $13,85 \%$ & 1 & Not Good \\
\hline Net Profit & $0,26 \%$ & $31,89 \%$ & $0,47 \%$ & 1 & Not Good \\
\hline & Total & & & 6 & \\
\hline & Average & & 1 & Not Good \\
\hline
\end{tabular}

Table 4. Directors of Employee Walfare Ratio Results

\begin{tabular}{ccccc}
\hline Years & \multicolumn{1}{c}{ Indonesia Muamalat Bank } & Scores & Predicates \\
\hline 2014 & & 63 Time & 3 & Good \\
\hline 2015 & 76 Time & 4 & Very Good \\
\hline 2016 & 15 Time & 1 & Not Good \\
\hline & Total & & 3 & Good \\
\hline
\end{tabular}




\section{Conclusions}

The results showed that the performance of Islamic Commercial Banks in Indonesia using the Islamicity Performance Index approach for the period 2014 to 2016 has the predicate "Not Good". There are several unsatisfactory ratios, namely the Zakat Performance ratio, the Equitable Distribution ratio, and the Directors-Employee Ratio. This shows that for the Zakat Performance ratio there is still a lack of Islamic banks to distribute their zakat in 2014-2016, for the Equitable Distribution ratio there is still little income distributed to stake holders, the intended stakeholders are qard recipients, bank employees, shareholders, and banks. itself, and the Directors-Employee Ratio shows that the difference in the welfare level of directors and employees in Islamic banks is still large.

\section{Acknowledgement}

The authors would like to thanks the related to party from North Sumatera Islamic University for their assistance in the completed this study.

\section{Author's Contributions}

All authors discussed the results and contributed to from the start to final manuscript.

\section{Conflict of Interest}

The authors declare that they have no competing interests.

\section{References}

Duantika, D. (2015). Analisis Perbandingan kinerja Bank Syariah Berdasarkan RGEC Dan Islamicity Performance Index. Jakarta: Fakultas Syariah Dan Hukum UIN Syarif Hidayatullah.

Dewanata Pandu, Hamida, dan Ahmad Nazir Gatot. (2016). The effect Of Intellectual Capital And Islamicity Performance Index To The Performance Of Islamic Bank Indonesia 2010-2014 Periods, Jurnal Riset Manejemen sains Indonesia (JRMSI) 7(2).

Hameed Shalul, Ade Wirman, Bactiar Alrazi, Mohd Nazli Bin Mohd. Nor, Sigit Pramono. (2004). Alternative Disclosure \& Performance measure For Islamic Banks, Malaysia: Depaterment of Accounting Internasional Islamic University Malaysia.

Hasan, Zubairi. (2009). Undang-Undang Perbankan Syariah, Januari 2009.

Prasetyo, Luhur. (2014). Corporate Social Responsibility (CSP) Bank Syariah Di Indonesia, Social Resnponsbility, Kodifikasia 8(1).

Sudarsono, Heri. (2008). Bank \& Lembaga Keuagan Syariah. Yogyakarta : Ekonisia

Sutedi, Adrian. (2009). Perbankan Syariah Tinjauan dan Beberapa Segi Hukum, Jakarta. 